\title{
Peran Konseling Laktasi dengan Penerapan Media terhadap Tingkat Keyakinan Diri dan Keberhasilan Menyusui pada Ibu Post partum
}

\author{
Catur E. Suksesty, ${ }^{1}$ Bethy S. Hernowo, ${ }^{2}$ Meita Damayanti, ${ }^{3}$ Farid Husin, ${ }^{4}$ Nanan Sekarwana, ${ }^{5}$ \\ Elmira N. Sumintardja, ${ }^{6}$ \\ ${ }^{1}$ Mahasiswa Program Studi Magister Kebidanan Fakultas Kedokteran Universitas Padjadjaran \\ ${ }^{2}$ Departemen Ilmu Patologi Anatomi Fakultas Kedokteran Universitas Padjadjaran \\ ${ }^{3,5}$ Departemen Ilmu Kesehatan Anak Fakultas Kedokteran Universitas Padjadjaran \\ ${ }^{6}$ Departemen Epidemiologi dan Biostatistika Fakultas Kedokteran Universitas Padjadjaran \\ ${ }^{6}$ Departemen Ilmu Psikologi Fakultas Psikologi Universitas Padjadjaran
}

\begin{abstract}
Abstrak
Pemberian Air Susu Ibu (ASI) yang dilakukan sejak usia dini dan dilanjutkan dengan ASI eksklusif selama 6 bulan dapat menurunkan angka kesakitan dan kematian bayi, serta meningkatkan tumbuh kembang bayi secara optimal. Namun, secara global masih sedikit bayi di bawah usia enam bulan yang diberikan ASI secara eksklusif, yaitu sebesar $40 \%$. Beberapa studi telah dilakukan tentang pentingnya ASI, tetapi angka pemberian ASI belum memuaskan. Salah satu penyebab rendahnya pemberian ASI, yaitu karena ketidaktahuan ibu tentang proses laktasi yang menyebabkan kurangnya keyakinan ibu untuk dapat menyusui bayinya. Ibu memerlukan informasi yang tepat dari tenaga kesehatan tentang proses laktasi. Informasi tersebut disampaikan dalam proses konseling laktasi dan wajib ibu ketahui mulai dari masa kehamilan. Tujuan penelitian ini adalah untuk menganalisis pengaruh penggunaan media dalam konseling laktasi terhadap keyakinan diri dan keberhasilan menyusui ibu post partum. Penelitian ini merupakan penelitian kuasi eksperimen dengan rancangan post test only with control group design. Pengambilan sampel dengan cara consecutive sampling sesuai kriteria inklusi, yaitu sebesar 30 ibu primigravida usia kehamilan 36 minggu sampai 1 bulan post partum. Instrumen yang digunakan, yaitu Breastfeeding Self-Efficacy Scale Form (BSESF) dan lembar observasi kemampuan menyusui sesuai dengan modul konseling menyusui 40 jam WHO/UNICEF tahun 2011. Rancangan analisis penelitian ini menggunakan uji T dan uji MannWhitney serta uji Rank Spearman untuk mencari korelasi dengan bantuan SPSS. Keyakinan diri pada usia kehamilan 36 minggu sampai 1 minggu post partum didapatkan nilai $\mathrm{p}<0,05$, sedangkan pada waktu 1 hari post partum sampai 1 minggu post partum didapatkan nilai $\mathrm{p}<0,01$. Tidak terdapat korelasi keyakinan diri terhadap kemampuan menyusui dan keberhasilan menyusui pada ibu post partum dengan nilap $\mathrm{p}>0,05$.
\end{abstract}

Kata Kunci : Keberhasilan menyusui, keyakinan diri, konseling laktasi, media informasi 
Korespondensi: Jl. Tanah Seratus RT 03/RW 12 No.26 Ciledug, Tangerang HP: 08568846436 ,email: catur_erty@y7mail.com

\title{
Lactation Counseling Roles with the Media Application Towards Self Efficacy and Success of Breastfeeding on Post partum Mothers
}

\begin{abstract}
Breastfeeding is performed at an early age and continued with exclusive breastfeeding for six months can reduce morbidity and infant mortality rates and improving infant growth optimally. However, globally still little babies under six months are exclusively breastfed is $40 \%$. Several studies have been conducted about the importance of breastfeeding, the numbers of breastfeeding are not satisfactory. One cause of low breastfeeding is due to ignorance about the process which led to a lack of confidence of mothers to breastfeed their babies. Mothers need accurate information from health workers about the process of lactation. This information is conveyed in the process of lactation counseling and mother shall know from pregnancy. The purpose of this study was to analyze the influence of media use in lactation counseling to self-efficacy and successful breastfeeding post partum mothers. This study is a quasi-experimental research (quasi experimental) with post test only control group design. Sampling by consecutive sampling method appropriate criteria are inclusive of 30 primigravida gestational age of 36 weeks to 1 month post partum. The instruments used are selfefficacy Breastfeeding Form Scale (BSESF) and the observation sheet in accordance with the module's ability to breastfeed breastfeeding counseling 40 hours WHO / UNICEF in 2011. The design of this research analysis using T test and Mann-Whitney test and Spearman's Rank test for correlations SPSS. Confidence at 36 weeks of gestation until one week post partum $p$ value $<0.05$, whereas at the time of 1 day to 1 week post partum post partum $p$ value $<0.01$. There is no correlation confidence in the ability of successful breastfeeding and breastfeeding on post partum mothers with nilap $\mathrm{p}>0.05$.
\end{abstract}

Keywords : Breastfeeding success, self-efficacy, lactation counseling, media information

\section{Pendahuluan}

Secara global, masih sedikit bayi di bawah usia enam bulan yang diberikan ASI secara eksklusif, yaitu sebesar $40 \%$. Organisasi Kesehatan Dunia (WHO) merekomendasikan beberapa hal tentang pemberian nutrisi pada bayi, yaitu bayi mulai menyusu dalam satu jam kehidupan, memberikan ASI eksklusif selama enam bulan, pengenalan tepat waktu makanan padat, dan ketepatan dalam memberikan makanan pendamping, serta terus menyusui hingga dua tahun atau lebih. ASI adalah salah satu cara yang paling efektif untuk menjamin kesehatan dan kelangsungan hidup anak. Sekitar 800.000 jiwa anak akan diselamatkan setiap tahun, jika mereka disusui dalam waktu satu jam kelahiran, kemudian hanya diberikan ASI selama enam bulan pertama kehidupan, dan terus menyusui sampai usia dua tahun. ${ }^{1}$

Beberapa studi telah dilakukan tentang pentingnya ASI, akan tetapi angka pemberian ASI belum memuaskan. Menurut hasil Riset kesehatan dasar tahun 2013, pemberian ASI di
Indonesia pada bayi 0 bulan adalah $52,7 \%$, pada bayi 1 bulan adalah $48,7 \%$, pada bayi 2 bulan adalah $46 \%$, pada bayi 3 bulan adalah $42,2 \%$, pada bayi 4 bulan adalah $41,9 \%$, pada bayi 5 bulan adalah $36,5 \%$ dan persentase terendah pada anak umur 6 bulan sebesar 30,2\%. ${ }^{2}$

Salah satu cara mencapai kesuksesan menyusui adalah adanya keyakinan diri. Breastfeeding self-efficacy merupakan keyakinan seseorang dalam kemampuannya untuk berhasil menyusui bayinya. Menurut Dennis, keyakinan ibu pada kemampuannya dalam menyusui akan memprediksi beberapa hal seperti ibu memilih untuk menyusui, seberapa banyak usaha yang ibu lakukan, peningkatan pola pikir ibu, dan bagaimana secara emosional ibu akan menanggapi kesulitan menyusui. ${ }^{3,4}$

Menyusui bayi selama 6 bulan atau lebih, seperti yang direkomendasikan oleh WHO, memerlukan tingkat keyakinan diri yang tinggi. Beberapa studi mengatakan tingkat keyakinan diri yang tinggi dapat memprediksi tingginya tingkat keberhasilan menyusui. Selain itu, IJEMC, Volume 3 No. 2, Juni 2016 |49 
adanya dukungan dari lingkungan keluarga atau tenaga kesehatan diduga berkorelasi terhadap tingginya keyakinan diri untuk berhasil menyusui bayinya. ${ }^{5}$

Begitu besarnya pengaruh keyakinan ibu dalam menyusui maka diperlukannya berbagai intervensi untuk meningkatkan keyakinan tersebut sehingga tercapai keberhasilan dalam menyusui. Intervensi yang beragam telah dilakukan seperti pemberian edukasi laktasi per individu ataupun melalui telepon, penyediaan media edukasi, dan penyediaan ruangan menyusui. Intervensi dapat dilakukan oleh tenaga kesehatan, konselor laktasi, dan temanteman sekitar. Penelitian menunjukkan intervensi dengan memberikan edukasi memiliki efek besar dalam meningkatkan pemberian ASI. ${ }^{5}$

Intervensi dengan cara pemberian konseling akan efektif bila dilakukan oleh konselor laktasi, konten berisi informasi mengenai ASI sebagai nutrisi yang baik untuk bayi, manfaat ASI, fisiologi menyusui, posisi, dan teknik perlekatan. Cara untuk mengatasi masalah menyusui serta sesi edukasi tersebut akan efektif bila berlangsung antara 30 hingga 90 menit. $^{6}$

Penggunaan media dalam konseling laktasi dapat berpengaruh besar dalam penyerapan informasi yang disampaikan. Berbagai macam media yang digunakan dalam konseling seperti leaflet yang diberikan kepada ibu, lembar balik, alat peraga laktasi, dan pemutaran film atau video sebagai alat bantu visual. Media pendidikan kesehatan dibuat berdasarkan prinsip bahwa pengetahuan yang ada pada setiap manusia diterima atau ditangkap melalui panca indera, semakin banyak indera yang digunakan untuk menerima sesuatu maka semakin banyak dan semakin jelas pengetahuan yang diperoleh. Berdasarkan observasi, proses konseling menjadi kurang efektif jika bidan tidak menggunakan media komunikasi tetapi lebih banyak ke arah penyampaian secara lisan dalam pemberian konseling. Media komunikasi yang digunakan konselor harus mampu memberikan informasi yang mudah diterima dan mudah diingat oleh ibu. ${ }^{6}$

Berdasarkan uraian di atas, tujuan dalam penelitian ini adalah untuk mengetahui peran konseling laktasi dengan penerapan media terhadap tingkat keyakinan diri dan keberhasilan menyusui pada ibu post partum.

\section{Metode}

Penelitian ini merupakan penelitian kuantitatif dengan rancangan quasi experiment, yaitu post test only design. Populasi dalam penelitian ini adalah seluruh ibu hamil primigravida dengan usia kehamilan 36 minggu sampai 1 bulan post partum di Bidan Praktek Mandiri (BPM), Kecamatan Ciledug, Kota Tangerang.

Pengukuran sampel menggunakan analisis kategorik tidak berpasangan, yaitu 60 responden (30 responden pada kelompok intervensi dan 30 responden pada kelompok kontrol). Pemilihan subjek dilakukan secara nonprobability/ nonrandom sampling dengan metode consecutive sampling, yaitu setiap subjek yang memenuhi kriteria inklusi dimasukkan dalam penelitian sampai kurun waktu tertentu berdasarkan urutan kedatangan responden di tempat penelitian sampai memenuhi jumlah sampel.

Media-media yang digunakan dalam penelitian ini diperoleh dari Sentra Laktasi Indonesia (SELASI) yang sudah sesuai dengan modul konseling menyusui 40 jam WHO/UNICEF tahun 2011. ${ }^{7}$ Media yang digunakan adalah lembar balik panduan konseling, leaflet, video, dan boneka peraga laktasi. Pelaksanaan konseling dilaksanakan sebanyak 3 kali yaitu pada saat kunjungan prenatal usia kehamilan 36 minggu, hari pertama post partum dan hari ketujuh post partum. Variabel yang dibahas dalam penelitian ini yaitu keyakinan diri ibu dalam menyusui dan keberhasilan menyusui.

Pengukuran keyakinan ibu dalam menyusui dilakukan setelah intervensi sebagai hasil dari post test yang dilakukan ditiga waktu tersebut menggunakan BSESF yang dikembangkan oleh Dennis dan Spaulding tahun 2010. Pada satu bulan post partum dilakukan evaluasi keberhasilan menyusui dengan dilakukannya pengamatan kemampuan menyusui dengan menggunakan lembar observasi pada masingmasing kelompok.

Analisis data penelitian menggunakan uji Mann-Whitney untuk mengetahui perbedaan nilai keyakinan diri pada kedua kelompok perlakuan, sedangkan uji Rank Spearman digunakan untuk melihat adanya korelasi antara keyakinan diri dengan keberhasilan menyusui. 
Hasil

Tabel 1. Karakteristik Responden pada Kedua Kelompok Penelitian

\begin{tabular}{lccc}
\hline \multicolumn{1}{c}{ Karakteristik } & $\begin{array}{c}\text { Kelompok Intervensi } \\
(\mathbf{n = 3 0})\end{array}$ & $\begin{array}{c}\text { Kelompok Kontrol } \\
(\mathbf{n = 3 0})\end{array}$ & Nilai p* \\
\hline Usia & $25(41,7 \%)$ & $23(38,3 \%)$ & 0,747 \\
Tidak risiko tinggi (20-35 tahun) & $5(8,3 \%)$ & $7(11,7 \%)$ \\
Risiko tinggi (<20 atau >35 tahun) & & & \\
Pendidikan & $24(40 \%)$ & $21(35 \%)$ & 0,551 \\
Tinggi (SMA, PT) & $6(10 \%)$ & $9(15 \%)$ & \\
Rendah (SD, SMP) & & & 0,784 \\
Pekerjaan & $19(31,7 \%)$ & $21(35 \%)$ & \\
Ibu Rumah Tangga & $11(18,3 \%)$ & $9(15 \%)$ & \\
Bekerja (PNS, Swasta, Wiraswasta) & & &
\end{tabular}

Berdasarkan tabel di atas, diketahui ketiga karakteristik responden atau variabel perancu tidak berbeda secara bermakna pada kedua kelompok perlakuan, yang ditunjukkan oleh nilai $\mathrm{p}>0,05$ sehingga dapat disimpulkan kedua kelompok memiliki karakteristik yang homogen sehingga layak untuk diperbandingkan.

Tabel 2. Perbedaan Keyakinan Diri Ibu dalam Menyusui pada Kelompok Intervensi dan Kontrol

\begin{tabular}{lccc}
\hline \multicolumn{1}{c}{ Keyakinan Diri (Skala 100) } & $\begin{array}{c}\text { Kelompok Intervensi } \\
(\mathbf{n = 3 0})\end{array}$ & $\begin{array}{c}\text { Kelompok Kontrol } \\
(\mathbf{n}=\mathbf{3 0})\end{array}$ & Nilai p* \\
\hline Pada usia kehamilan 36 minggu & & & $<0,001^{*}$ \\
Rata-rata (SD) & 5,0 & 4,2 & \\
Median & 59,0 & 53,5 & \\
Rentang & $48,2-69,6$ & $44,7-60,7$ & \\
Pada 1 hari post partum & 6,5 & & $0,004 * *$ \\
Rata-rata (SD) & 62,5 & 5,1 & \\
Median & $51,8-76,8$ & 59,0 & \\
Rentang & & $48,2-71,4$ & \\
Pada 1 minggu post partum & 8,0 & & \\
Rata-rata (SD) & 67,8 & 5,0 & \\
Median & $51,8-80,4$ & 59,0 & \\
Rentang & & $48,2-7,0$ & \\
\hline
\end{tabular}

Keterangan: *) Uji t; **) Uji Mann-whitney

Berdasarkan tabel di atas, terlihat nilai median keyakinan diri ibu dalam menyusui pada kelompok intervensi senantiasa mengalami peningkatan mulai dari usia kehamilan 36 minggu sampai 1 minggu post partum, yaitu 59,0 menjadi 67,8, sedangkan pada kelompok kontrol nilai median keyakinan diri ibu dalam menyusui meningkat hanya pada saat usia kehamilan 36 minggu dan 1 hari post partum, yaitu dari 53,5 menjadi 59,0. Hasil uji t dan uji Mann-whitney menunjukkan ada perbedaan yang sangat bermakna baik konseling yang dilakukan pada usia kehamilan 36 minggu, 1 hari post partum, maupun 1 minggu post partum.

Tabel 3. Perbedaan Kemampuan Menyusui pada Kelompok Kontrol dan Kelompok Intervensi

\begin{tabular}{lccc}
\hline \multicolumn{1}{c}{ Variabel } & $\begin{array}{c}\text { Kelompok Intervensi } \\
(\mathbf{n = 3 0 )}\end{array}$ & $\begin{array}{c}\text { Kelompok Kontrol } \\
(\mathbf{n = 3 0 )}\end{array}$ & Nilai $\mathbf{p}^{*}$ \\
\hline Kemampuan Menyusui & 91,0 & & 0,010 \\
Median & $40,9-100$ & 72,7 & \\
Rentang & & $40,9-100$ & \\
\hline
\end{tabular}

Keteranngan: *) Uji Mann-Whitney 
Berdasarkan tabel 3 menunjukkan kemampuan menyusui pada kelompok yang diberi konseling laktasi dengan penerapan media lebih tinggi dibandingkan kelompok yang diberi konseling laktasi dengan asuhan standar. Hasil uji Mann-Whitney didapatkan nilai $\mathrm{p}<0,05$.

Tabel 4. Perbedaan Keberhasilan Menyusui pada Kelompok Kontrol dan Kelompok Intervensi

\begin{tabular}{lccc}
\hline Keberhasilan Menyusui & $\begin{array}{c}\text { Kelompok Intervensi } \\
(\mathbf{n}=\mathbf{3 0})\end{array}$ & $\begin{array}{c}\text { Kelompok Kontrol } \\
(\mathbf{n}=\mathbf{3 0})\end{array}$ & Nilai p* \\
\hline Berhasil & $26(86,7 \%)$ & $20(66,7 \%)$ & 0,067 \\
Tidak berhasil & $4(13,3 \%)$ & $10(33,3 \%)$ & \\
\hline Keerangan: ${ }^{*}$ Uji Chi Kuadrat & &
\end{tabular}

Berdasarkan tabel 4 menunjukkan pada kelompok intervensi, ibu berhasil menyusui lebih banyak sejumlah 26 orang (86,7\%) dibandingkan ibu yang tidak berhasil menyusui bayinya, yaitu sebanyak 4 orang (13,3\%). Pada kelompok kontrol, ibu yang berhasil menyusui pada 1 bulan post partum sebanyak 20 orang
$(66,7 \%)$, sedangkan ibu yang tidak berhasil menyusui bayinya sebanyak 10 orang $(33,3 \%)$. Hasil uji Chi Kuadrat menunjukkan tidak terdapat perbedaan yang bermakna antara dua kelompok dalam keberhasilan menyusui di 1 bulan post partum.

Tabel 5. Perbandingan Persentase Peningkatan Keyakinan Diri Ibu dalam Menyusui antara Kelompok Intervensi dan Kelompok Kontrol

\begin{tabular}{lccc}
\hline \multicolumn{1}{c}{$\begin{array}{c}\text { \% Peningkatan Keyakinan Diri } \\
\text { (Median) }\end{array}$} & $\begin{array}{c}\text { Kelompok } \\
\text { Intervensi } \\
(\mathbf{n = 3 0 )}\end{array}$ & $\begin{array}{c}\text { Kelompok } \\
\text { Kontrol } \\
(\mathbf{n = 3 0 )}\end{array}$ & Nilai p* \\
\hline UK 36 minggu - 1 hari post partum & 9,4 & 13,6 & 0,169 \\
UK 36 minggu - 1 minggu post partum & 20,8 & 11,8 & 0,030 \\
1 hari post partum - 1 minggu post partum & 6,5 & 0 & 0,000 \\
\hline
\end{tabular}

Keterangan: *) Uji Mann-Whitney

Berdasarkan tabel 5 terlihat persentase peningkatan keyakinan diri dalam menyusui pada kelompok intervensi lebih meningkat di usia kehamilan 36 minggu sampai 1 minggu post partum (20,8\%), sedangkan pada kelompok kontrol persentase peningkatan terlihat lebih tinggi di usia kehamilan 36 minggu sampai 1 hari post partum (13,6\%). Hasil uji MannWhitney didapatkan nilai $\mathrm{p}>0,05$ pada usia kehamilan 36 minggu sampai 1 hari post partum, artinya tidak terdapat peningkatan yang bermakna pada kedua kelompok di waktu tersebut. Pada usia kehamilan 36 minggu sampai 1 minggu post partum didapatkan nilai $\mathrm{p}<0,05$, sedangkan pada waktu 1 hari post partum sampai 1 minggu post partum menunjukkan terdapat peningkatan yang sangat bermakna pada kedua kelompok di waktu tersebut.

Tabel 6. Korelasi Keyakinan Diri Ibu dalam Menyusui dengan Kemampuan Menysusui pada Kelompok Intervensi dan Kelompok Kontrol

\begin{tabular}{lcc}
\hline \multicolumn{1}{c}{ Kemampuan Menyusui } & Koefisien Korelasi & Nilai P* \\
\hline $\begin{array}{l}\text { Keyakinan diri pada umur kehamilan } \\
\text { minggu }\end{array}$ & $-0,335$ & 0,070 \\
$\begin{array}{l}\text { Keyakinan diri pada } 1 \text { hari post partum } \\
\text { Keyakinan diri pada 1 minggu post partum }\end{array}$ & 0,151 & 0,426 \\
\hline
\end{tabular}

Keterangan: *) Uji Rank Spearman 
Tabel 6 memperlihatkan kemampuan menyusui tidak berkorelasi dengan keyakinan diri, dapat dilihat dari nilai $\mathrm{p}>0,05$. Hasil ini menunjukkan adanya korelasi yang sangat lemah antara keyakinan diri pada usia kehamilan 36 minggu dengan kemampuan menyusui $(\mathrm{r}=0,335)$ dan koefisiensi korelasi yang lemah antara keyakinan diri pada 1 hari dan 1 minggu post partum.

\section{Tabel 7. Korelasi Keyakinan Diri Ibu dalam Menyusui dengan Keberhasilan Menyusui pada Kelompok Intervensi dan Kelompok Kontrol}

\begin{tabular}{lcc}
\hline \multicolumn{1}{c}{ Keberhasilan Menyusui } & Koefisien Korelasi & Nilai P* \\
\hline Keyakinan diri pada UK 36 minggu & $-0,017$ & 0,931 \\
Keyakinan diri pada 1 hari post partum & $-0,273$ & 0,145 \\
Keyakinan diri pada 1 minggu post partum & $-0,334$ & 0,071 \\
\hline
\end{tabular}

Keterangan: *) Uji Rank Spearman

Tabel 7 memperlihatkan keberhasilan menyusui tidak berkorelasi dengan keyakinan diri. Hasil ini menunjukkan adanya koefisiensi korelasi yang sangat lemah antara keyakinan diri pada usia kehamilan 36 minggu, 1 hari post partum, dan 1 minggu post partum dengan keberhasilan menyusui.

\section{Diskusi}

Pada penelitian ini, seluruh responden penelitian adalah ibu hamil primigravida yang belum mempunyai pengalaman menyusui. Hal ini dapat memengaruhi tingkat keyakinan diri dalam proses menyusui. Breastfeeding SelfEfficacy (BSE) adalah keyakinan diri seorang ibu pada kemampuannya untuk menyusui atau memberikan ASI pada bayinya. BSE merupakan variabel yang penting dalam durasi menyusui, karena memprediksi apakah ibu memilih menyusui atau tidak, berapa banyak usaha yang dilakukan ibu untuk menyusui bayinya, bagaimana pola pikir ibu untuk menyusui bayinya, meningkat atau menyerah, dan bagaimana ibu menanggapi secara emosional kesulitan untuk menyusui bayinya. ${ }^{8}$

Berdasarkan hasil penelitian ini, rata-rata keyakinan diri ibu dalam menyusui pada kelompok intervensi mengalami peningkatan mulai dari usia kehamilan 36 minggu sampai 1 minggu post partum, yaitu 5,0 menjadi 8,0 . Hasil uji statistik didapatkan nilai $\mathrm{p}<0,01$ menunjukkan ada perbedaan yang sangat bermakna pada keyakinan diri antara kedua kelompok.

Tingkat keyakinan diri ibu dalam menyusui pada kelompok yang dilakukan konseling laktasi dengan penerapan media dan konseling laktasi dengan asuhan standar sama-sama mengalami peningkatan, namun pada kelompok intervensi lebih tinggi dibandingkan kelompok kontrol. Bila dilihat dari nilai rentang (minimummaximum) keyakinan diri pada kelompok intervensi belum mencapai nilai yang diinginkan, yaitu masih dalam kategori "kadangkadang yakin" dan "yakin". Hal ini dapat disebabkan karena pada penelitian ini peneliti tidak melakukan evaluasi atau penilaian tingkat pengetahuan yang didapat setelah diberikan penyampaian informasi dengan menggunakan media seperti lembar balik, leaflet, dan video yang berisi seputar informasi menyusui.

Peneliti berharap penggunaan berbagai media dalam konseling laktasi dapat mempermudah penyampaian informasi sehingga dapat memengaruhi tingkat keyakinan diri ibu dalam menyusui menjadi "sangat yakin". Menurut teori Edgar Dale ketika penggunaan media pembelajaran lebih konkrit atau dengan pengalaman langsung maka pesan (informasi) pada proses pembelajaran yang disampaikan akan tersampaikan dengan baik, tetapi sebaliknya jika penggunaan media pembelajaran semakin abstrak maka pesan (informasi) akan sulit untuk diterima dengan kata lain seseorang menghadapi kesulitan dalam memahami dan mencerna apa yang disampaikan oleh informan.

Pada hasil penelitian tidak terdapat persentase peningkatan yang bermakna pada keyakinan diri ibu di saat usia kehamilan 36 minggu sampai 1 hari post partum. Hal ini kemungkinan terjadi karena kontak I konseling laktasi baru dilakukan pada saat usia kehamilan 36 minggu dan hanya dilakukan 1 kali saat antenatal sehingga pada 1 hari post partum responden masih belum merasa mampu untuk melakukan proses menyusui. Hal ini bisa dilihat IJEMC, Volume 3 No. 2, Juni 2016 | 53 
dari latar belakang responden yaitu mereka yang belum memiliki pengalaman menyusui.

Pada kelompok yang diberikan konseling laktasi dengan asuhan standar nilai rata-rata keyakinan diri ibu dalam menyusui juga meningkat dari 4,2 pada saat usia kehamilan 36 minggu menjadi 5,0 pada 1 minggu post partum. Konseling laktasi dengan asuhan standar yaitu konseling yang dilakukan secara verbal, yaitu hanya memberikan nasihat dan penjelasan seputar menyusui secara lisan. Seperti kelompok kontrol konseling laktasi dengan asuhan standar dilakukan oleh bidan setempat dimana peneliti tidak mengukur masing-masing pengetahuan dan kemampuan berkomunikasi pada bidan tersebut sehingga hasil penelitian keyakinan diri ibu menyusui pada kelompok kontrol selalu meningkat ditiga waktu yang berbeda (kehamilan 36 minggu, 1 hari post partum dan 1 minggu post partum)..$^{7,8,9}$

Menurut Mcqueen (2009) dalam penelitiannya menunjukkan bahwa intervensi dengan memberikan edukasi memiliki efek besar dalam meningkatkan pemberian ASI Konseling laktasi merupakan rangkaian-rangkaian kontak atau hubungan secara langsung dengan individu yang tujuannya memberikan bantuan dalam merubah sikap dan tingkah laku. Dalam proses konseling laktasi bidan memberikan edukasi tentang seputar menyusui dan mengatasi masalah yang dialami oleh ibu dalam menyusui. ${ }^{4,8,10}$

Komponen utama dari suatu proses konseling, serta keterampilan dasar yang harus dimiliki oleh seorang konselor laktasi adalah: kemampuan berkomunikasi. Konselor laktasi dapat membuat ibu membuka diri, menyadari sendiri persepsi keliru yang selama ini mungkin dimilikinya terkait dengan kegiatan menyusui, serta kemudian berkeinginan untuk mengubah atau memperbaiki persepsi keliru tersebut sehingga kegiatan menyusui dapat berjalan lebih lancar. Seorang Konselor Laktasi yang tidak dapat berkomunikasi dengan baik, akan mengalami tantangan yang lebih besar ketika sedang menjalankan tugasnya. ${ }^{11,12}$

Pada penelitian ini penggunaan media dalam konseling laktasi membantu menghindari kesalahan bicara pada konselor dan sebagai alat bantu unuk menyampaikan informasi yang relevan seputar menyusui sehingga diharapkan keyakinan diri ibu dalam menyusui meningkat dimana ibu sangat yakin bisa menyusui bayinya.
Keberhasilan menyusui merupakan kemampuan ibu untuk memberikan ASI saja pada bayi dengan melakukan teknik menyusui yang benar, yaitu posisi menyusui, dan pelekatan mulut bayi pada payudara ibu. Pencapaian keberhasilan dalam menyusui diperlukan teknik-teknik menyusui yang benar. Teknik menyusui yang benar adalah cara ibu memberikan ASI kepada bayi dengan pelekatan dan posisi yang baik dan benar. Teknik menyusui merupakan salah satu faktor yang berpengaruh dalam pemberian ASI. Teknik menyusui yang benar dapat diajarkan oleh para konselor kepada ibu primipara mulai dari masa prenatal. ${ }^{13}$

Tabel 3 menunjukkan bahwa kemampuan menyusui pada kelompok yang diberi konseling laktasi dengan penerapan media lebih tinggi dibanding kelompok yang diberi konseling laktasi dengan asuhan standar didapatkan nilai $\mathrm{p}<0,05$. Hasil kemampuan menyusui didapatkan dari hasil pengamatan proses menyusui pada 1 bulan post partum. Peneliti mengukur seberapa mampu ibu melakukan teknik menyusui yang benar. Lembar pengamatan kemampuan menyusui yang digunakan didapat dari modul konseling menyusui 40 jam WHO/UNICEF.

Pada penelitian ini, kelompok intervensi dilakukan konseling laktasi dengan penerapan media untuk mempermudah penyampaian informasi dan diharapkan kemampuan menyusui akan lebih meningkat. Media yang digunakan adalah lembar balik, leaflet, video, dan boneka peraga. Pada media lembar balik dan leaflet berisi informasi tentang pentingnya ASI dan menjelaskan teknik menyusui yang benar, sedangkan pada video menjelaskan dan mengilustrasikan secara audio dan visual bagaimana proses menyusui yang benar dan boneka peraga digunakan untuk mendemonstrasikan teknik menyusui sehingga ibu dapat belajar dan mampu mengaplikasikan secara benar sesuai dengan apa yang diperlihatkan dalam media-media tersebut., ${ }^{3,714}$

Pelayanan konseling perlu didukung sarana penunjang untuk mendapatkan hasil yang maksimal yaitu ruangan tempat pelaksanaan konseling harus nyaman dan didukung dengan sarana bahan penunjang konseling yang sesuai. Media yang digunakan dalam konseling seperti leaflet yang diberikan kepada ibu, lembar balik, alat peraga laktasi, dan pemutaran film atau 
video sebagai alat bantu visual merupakan sarana penunjang dalam penyampaian informasi.

Berdasarkan Tabel 4 menunjukkan bahwa pada kelompok intervensi ibu yang berhasil menyusui pada 1 bulan post partum lebih banyak sejumlah 26 orang $(86,7 \%)$ dibandingkan ibu yang tidak berhasil menyusui bayinya yaitu sebanyak 4 orang $(13,3 \%)$. Pada kelompok kontrol ibu yang berhasil menyusui pada 1 bulan post partum sebanyak 20 orang $(66,7 \%)$ sedangkan ibu yang tidak berhasil menyusui bayinya sebanyak 10 orang $(33,3 \%)$ dan didapatkan nilai $\mathrm{p}>0,05$ yang berarti bahwa tidak terdapat perbedaan yang bermakna antara dua kelompok dalam keberhasilan menyusui di 1 bulan post partum.

Penelitian ini dilakukan pada ibu primipara, seorang ibu primipara membutuhkan banyak informasi dan pengetahuan untuk anak pertamanya sehubungan dengan kegiatan menyusui, terutama pengetahuan, dukungan dan keterampilan menyusui yang benar.Semua informasi tersebut terkadang tidak secara lengkap didapatkan karena berbagai keadaan seperti kondisi ibu yang masih lemah pasca melahirkan, dukungan keluarga yang tidak adekuat, serta hubungan dan fungsi keluarga yang belum optimal. Peran konselor laktasi sangat dibutuhkan terutama pada ibu primipara sebagai bentuk dukungan dalam meningkatnya keberhasilan dalam pemberian ASI. ${ }^{15}$

Pada kelompok intervensi dan kelompok kontrol bidan atau konselor sama-sama memberikan motivasi pada ibu untuk dapat memberikan ASI saja pada bayinya agar bisa berhasil untuk memberikan ASI secara eksklusif. Pada setiap kali dilakukannya konseling laktasi baik itu pada kelompok dengan penerapan media ataupun dengan asuhan standar konselor selalu memberikan rangkaian informasi yang relevan tentang pentingnya ASI pada bayi.Teknik berkomunikasi pada saat melakukan konseling sangat diperlukan agar tujuan dari konseling dapat tercapai. Pencapaian keberhasilan dalam menyusui memerlukan keyakinan diri yang kuat pada ibu dan kemampuan yang baik dalam menyusui bayinya sehingga bayi hanya diberikan ASI diawal kehidupannya.

Tabel 6 memperlihatkan bahwa kemampuan menyusui tidak berkorelasi dengan keyakinan diri. Hasil ini menunjukkan adanya koefisiensi korelasi yang sangat lemah antara keyakinan diri pada usia kehamilan 36 minggu dengan kemampuan menyusui dan korelasi yang lemah antara keyakinan diri pada 1 hari dan 1 minggu post partum.

Keberhasilan menyusui merupakan kemampuan ibu untuk memberikan ASI saja pada bayi dengan melakukan teknik menyusui yang benar, yaitu: posisi menyusui, dan pelekatan mulut bayi pada payudara ibu. Pencapaian keberhasilan dalam menyusui diperlukan teknik-teknik menyusui yang benar. Teknik menyusui yang benar adalah cara ibu memberikan ASI kepada bayi dengan pelekatan dan posisi yang baik dan benar. Teknik menyusui merupakan salah satu faktor yang berpengaruh dalam pemberian ASI. Peran konselor laktasi sangat dibutuhkan terutama pada ibu primipara sebagai bentuk dukungan dalam meningkatnya keberhasilan menyusui. Teknik menyusui yang benar dapat diajarkan oleh para konselor kepada ibu primipara mulai dari masa prenatal. Pemberian konseling laktasi akan menumbuhkan keyakinan diri dalam menyusui sehingga keyakinan tersebut akan mendorong ibu untuk mampu melakukan teknik menyusui dengan benar, namun dari hasil korelasi pada penelitian ini tidak terdapat hubungan antara keyakinan diri dengan kemampuan menyusui. Hal ini dapat disebabkan karena pengamatan kemampuan menyusui dilakukan hanya 1 kali pada saat ibu kunjungan ulang 1 bulan post partum. Pada saat pengamatan peneliti tidak menghubungkan adanya faktor lain yang menyebabkan ibu kurang mampu melakukan teknik menyusui. ${ }^{10-12}$

Tabel 7 memperlihatkan bahwa keberhasilan menyusui tidak berkorelasi dengan keyakinan diri. Hasil ini menunjukkan adanya koefisiensi korelasi yang sangat lemah antara keyakinan diri pada usia kehamilan 36 minggu, 1 hari post partum, 1 minggu post partum dengan pemberian ASI saja pada bayi.

Hasil penelitian ini tidak sesuai dengan teori, yaitu semakin banyak ibu mendapatkan dukungan dari petugas kesehatan atau peer konselor yang telah dilatih konseling menyusui, maka semakin mudah bagi ibu untuk mempertahankan menyusui. Pada penelitian ini kelompok intervensi diberikan konseling laktasi dengan menggunakan berbagai media seperti leaflet, panduan konseling, video menyusui dan 
alat peraga seperti boneka untuk melakukan demonstrasi menyusui. Penggunaan media ini bertujuan untuk menyampaikan informasi seputar menyusui dengan lebih kongkrit sehingga responden dapat memahami dan dapat mengaplikasikannya, sedangkan pada kelompok kontrol hanya dilakukan asuhan standar pada saat konseling laktasi dimana penyampaian informasi masih bersifat abstrak sehingga responden harus mampu membayangkan bagaimana teknik menyusui yang benar. Peneliti berharap dengan penggunaan media saat dilakukannya konseling dapat memberikan dampak yang lebih besar dalam praktek menyusui sehingga keberhasilan menyusui pun akan terwujud, namun dari hasil penelitian tidak terbukti adanya hubungan antara keyakinan diri dengan keberhasilan menyusui. Hal ini kemungkinan bisa terjadi karena pada saat penilaian keyakinan diri peneliti tidak menggali lagi secara mendalam jawaban atau pernyataan dari ibu. Pada hasil penilaian keyakinan diri pada responden masih terdapat kategori "kadang-kadang yakin" yang artinya ibu masih khawatir akan kemampuannya memberikan ASI pada bayinya. Masih ada perasaan dalam diri ibu bahwa ia merasa ASInya tidak cukup untuk memenuhi kebutuhan nutrisi bayinya sehingga masih terdapat ibu yang memberikan susu formula pada bayinya.

Hasil penelitian ini mengkonfirmasi berbagai penelitian sebelumnya, menurut Entwistle dkk tahun 2010 menyatakan salah satu faktor penting dari ibu tidak memberikan ASI kepada bayinya adalah keyakinan diri ibu untuk menyusui atau BSE. Menurut Dennis (2003) BSE menentukan ibu untuk memilih menyusui atau tidak, berapa banyak usaha yang dilakukan ibu untuk menyusui bayinya, bagaimana pola pikir ibu untuk menyusui bayinya dan bagaimana ibu menanggapi secara emosional kesulitan untuk menyusui bayinya. ${ }^{14,16}$

\section{Simpulan}

Tingkat keyakinan diri dan kemampuan menyusui pada kelompok yang diberikan konseling laktasi dengan penerapan media lebih tinggi dibanding kelompok yang diberikan konseling laktasi dengan asuhan standar. Media yang digunakan dalam konseling laktasi, yaitu lembar balik, leaflet, video, dan boneka peraga memiliki pengaruh yang sama dalam meningkatkan keyakinan diri ibu dalam menyusui. Oleh karena itu, tenaga kesehatan perlu mengaplikasikan teknik konseling laktasi dengan penerapan media untuk mendukung keberhasilan menyusui.

\section{Daftar Pustaka}

1. United Nations Children's Fund (UNICEF). The state of the world's Children. New York: Author; 2013

2. Riskesdas. Laporan riset kesehatan dasar. Jakarta: Badan Penelitian dan Pengembangan Kesehatan Kementrian Kesehatan RI; 2013

3. Awano K, Shimada K. Development and evaluation of a self care program on breastfeeding in Japan:A quasi-experimental study. International Breastfeeding Journal. 2010; 5 : 9. 1186-1746

4. Karen A. McQueen. Improving Breastfeeding Outcomes: A Pilot Randomized Controlled Trial Of A Self Efficacy Intervention With Primiparous Mother. University of Toronto. 2009

5. Difrisco et al. Factors Associated with Exclusive Breastfeeding 2 to 4 weeks following discharge from a large, urban, academic medical center striving for baby friendly designation. The Journal of Perinatal Education. 2011; vol. 20. 28-35

6. Pintrich, P.R \& Schunk, D. H. Motivation In Education : Theory, Research, and applications. Englewoodcliffs NJ : Mernill-Prentice-Hall. 2002.vol.17. 459-70

7. Sentra Laktasi Indonesia. 2011. Pelatihan Konseling Menyusui, Modul 40 Jam WHO/UNICEF (Revisi 2011). Hal 24-75

8. Charles Fadel. Multimodal Learning Through Media: What the Research Says. Cisco Systems; 2008

9. Keemer F. Breastfeeding self-efficacy of women using second-line strategies for Health term infants in the First week post partum: an Australian observational study. International Breastfeeding Journal. 2013; vol. 12. $8-18$

10. Lavender $\mathrm{T}$ et al. Breastfeeding Expectations Versus Reality: A Clusterrandomized Controlled Trial. BJOG : An International Journal Of Obstetrics \& Gynecology. $2005 ; 112: 8.1047-53$

11. World Health Organization. Community-Based strategies for Breastfeeding Promotion and Support in Developing Countries. 2010

12. Dennis C.L. The Breastfeeding Self-Efficacy Scale : Psychometric assessment of The Short From. JOGNN. 2003; 32, 734-44

13. Spaulding DM, Dennis CL. Psychometric testing of the breastfeeding self-efficacy scale-short for min a sampel of Black women in the United states. Research in Nursing and Health. 2010; 33: 111-9

14. Spaulding DM, Gore R. Breastfeeding self-efficacy in women of african descent. JOGNN. 2009; 38. 230-4

15. Woolfolk A. E. Educational Psychology. USA. Allyn \& Bacon. 2004

16. Entwistle F, Kendall S, Mead M. Breastfeeding support-the importance of self-efficacy for low-income women. Maternal and Child Nutrition.2010; 6, 228-42. 